\title{
Erosão da orla costeira Grande-Bispo, ilha de Mosqueiro, Belém-PA, através da análise de indicadores
}

\author{
Erosion of the Grande-Bispo shore, Mosqueiro island, Belém-Pará, \\ through the analisis of indicators
}

\author{
Carmena Ferreira de França'; Rhuan Rodrigo Pereira e Silvall; \\ José Luiz do Amaral Ferreira Júnior III'; Fernando Alves de Araújoiv
}

\section{RESUMO}

O presente trabalho tem como área de estudo a orla costeira Grande-Bispo, localizada na ilha de Mosqueiro, Belém-Pará, contexto estuarino da baía de Marajó, a qual se destaca pelas modificações decorrentes da erosão e por ser uma das áreas de ocupação mais antiga da ilha e densamente urbanizada, tem como principal objetivo caracterizar a morfodinâmica da orla e a definição dos subsetores mais erosivos da mesma. A análise baseia-se na distribuição espacial e na quantificação de indicadores de dinâmica costeira. Os indicadores adotados são: variação da linha de costa (borda das falésias e promontórios), largura do arco praial, posição da linha de maré alta, granulometria praial, feições erosivas/acumulativas, altura de falésias, tipo e condição da vegetação e conservação das construções. Os dados foram obtidos através de interpretação de imagens de satélite e inventários de campo. A orla estudada compõe um cenário morfodinâmico diversificado, onde a erosão predomina, mas se manifesta com intensidade desigual. A análise da posição da linha de costa por imagens orbitais revela baixa erosão na orla Grande e estabilidade na orla do Bispo, no intervalo 1984-2017. Na escala temporal de curto período, os indicadores levantados em campo mostram média erosão na parte centro-sul da orla Grande e alta erosão na parte norte e na orla do Bispo.

Palavras-chave: Costa; Dinâmica; Erosão; Geoindicadores

\begin{abstract}
This present paper has as field of study the shore of Grande-Bispo, located at the Mosqueiro Island, Belém-Pará, estuarine environment of Marajó Bay, which stands out for the modifications caused by erosion and for being one of the earliest occupation sectors from the island and is highly urbanized, aims the morphodynamical characterization of the shore and the definition of its most erosive sectors. The analysis is based on the spatial distribution and indicators quantification of coastal dynamics. The indicators applied are: coastline variation (edges of cliffs and headlands), beach arc width, high tide line position, beach grain size, erosive/accumulative forms, cliffs height, vegetation condition and type and constructions conservation. The data were obtained by satellite image interpretation and field inventories. The studied shore composes a diversified morphodynamical scenario, which erosion prevails, but manifests itself with uneven intensity. The analysis of the coastline position by orbital images reveals low erosion at the Grande shore and stability at the Bispo shore, between 1984 and 2017. In a short period time scale, the indicators collected in field show medium erosion at the middle south portion of Grande shore and high degree erosion at the north portion and at Bispo shore.
\end{abstract}

Keywords: Coast; Dynamics; Erosion; Geoindicators

Universidade Federal do Pará.PA, Brasil - carmena@ufpa.br - https://orcid.org/0000-0001-8879-5191

" Universidade Federal do Pará.PA, Brasil - rhuanrodrigosilva@gmail.com - https://orcid.org/0000-0003-4506-6049

III Universidade Federal do Pará.PA, Brasil - joseamaral@gmail.com - https://orcid.org/0000-0002-2059-4067

IV Universidade Federal do Pará.PA, Brasil - mcsfernando@gmail.com - https://orcid.org/0000-0002-7472-4680 


\section{INTRODUÇÃO}

A zona costeira é compreendida como um espaço de interações, onde atuam fatores físicos de origem continental, marinha e atmosférica. Isso explica em parte o dinamismo dessa área transicional, que se traduz em constantes mudanças morfológicas, vegetacionais e sedimentológicas. A erosão e a acumulação são fenômenos frequentes, porém impactantes no sentido de provocarem alterações significativas no balanço sedimentar, na morfometria praial, no gradiente topográfico, na cobertura vegetal e na posição da linha de costa (SOUZA et al., 2005). Essas modificações podem ser monitoradas e analisadas através de elementos indicadores, registros ou testemunhos dos processos em curso (FORBES; LIVERMAN, 1996).

A área de estudo, foco deste trabalho, insere-se no contexto estuarino da baía de Marajó, pertencente à zona costeira paraense, onde a ação das marés, ondas, ventos e chuvas, com suas variações sazonais, propiciam condições de instabilidade e de desenvolvimento de processos erosivos. Ao longo do tempo, tais processos modelaram a configuração costeira, atribuindo-Ihe características particulares.

Mais especificamente, a orla Grande-Bispo localiza-se na porção sudoeste da ilha de Mosqueiro, margem leste da baía de Marajó, município de Belém, Pará, entre as coordenadas $1^{\circ} 08^{\prime}$ a $1^{\circ} 09^{\prime}$ de latitude sul e $48^{\circ} 27^{\prime}$ a $48^{\circ} 28^{\prime}$ de longitude oeste (Figura 1). Devido à posição geográfica, é uma área exposta a marés semidiurnas cujas amplitudes alcançam, no máximo, 3,9 m durante as sizígias de março, abril e setembro (BRASIL, 2018). Entretanto, há significativa atuação de ondas que podem atingir alturas de $1 \mathrm{~m}$ ou 1,5 m em condições de ventos do quadrante $\mathrm{N}-\mathrm{NE}$, mais fortes no período de julho a novembro. A orla é também influenciada por um regime pluviométrico sazonal com maior concentração de chuvas no trimestre de janeiro a março (PINHEIRO, 1987).

O relevo costeiro é composto por praias arenosas de enseada, contornadas por falésias e promontórios com alturas entre 3 e $6 \mathrm{~m}$, possivelmente as mais altas da ilha de Mosqueiro. Essas escarpas formam-se na borda dos tabuleiros e baixos platôs sedimentares da Formação Barreiras/Pós-Barreiras. 
Figura 1 - Localização da orla Grande-Bispo na porção sudoeste da ilha de Mosqueiro, município de Belém-PA

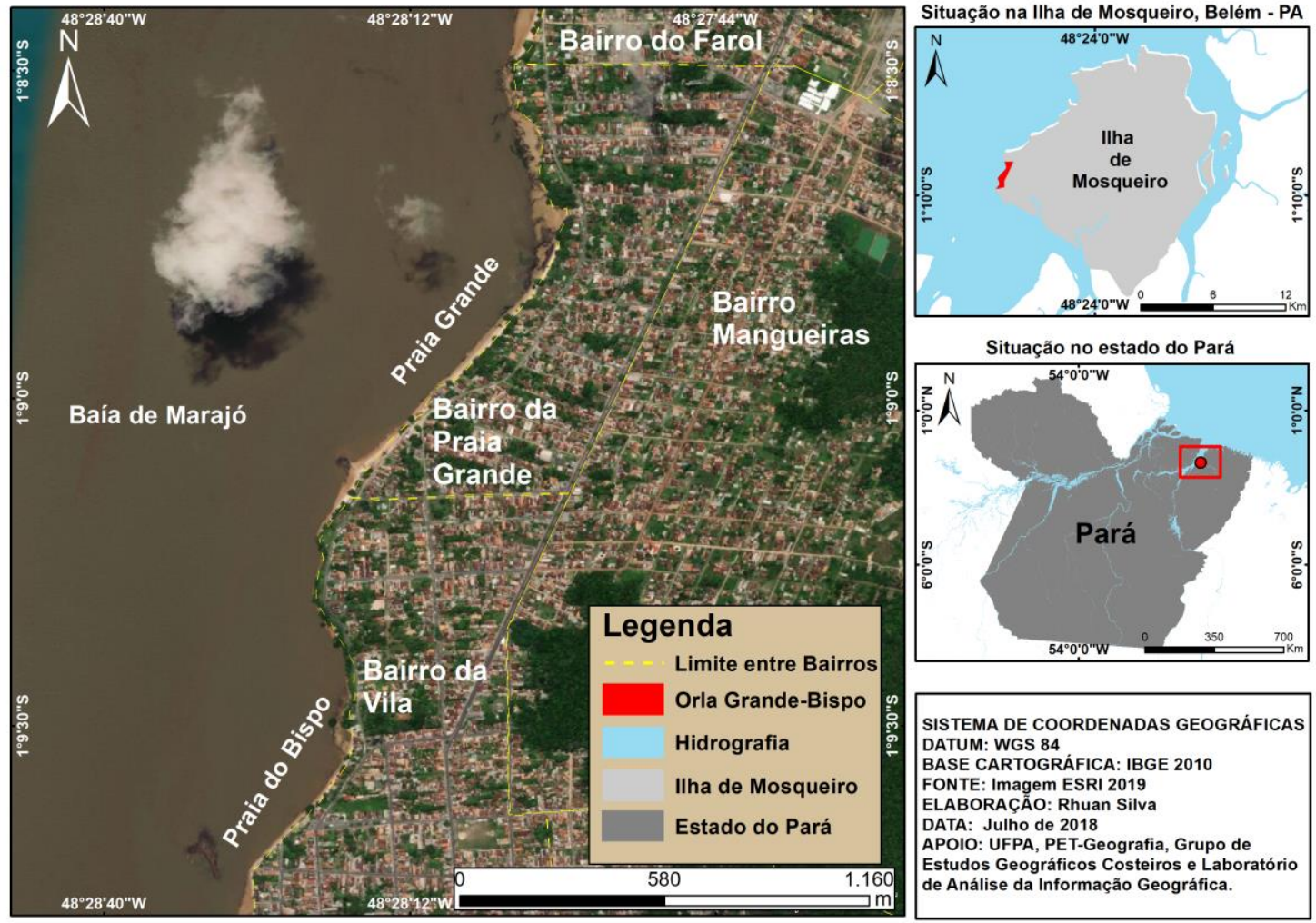

Organização dos autores (2018)

Com extensão de 3 km, a orla Grande-Bispo encontra-se dentre os setores de ocupação urbana mais antiga da ilha, cujos registros remontam ao final do século XIX e início do século XX (MEIRA FILHO, 1978). Trata-se de uma área densamente urbanizada, onde as construções e a infraestrutura urbana estendem-se desde o topo dos platôs, falésias até a porção superior das praias. É provida de linhas de transporte coletivo urbano e interurbano, e congrega estabelecimentos residenciais (inclusive de segundas residências) e comerciais. Tais elementos, associados às peculiaridades físicas, tornam a área populosa e bastante frequentada. Nos períodos de veraneio, férias escolares, feriados e finais de semana, cresce o fluxo de pessoas em busca de lazer, trabalho, descanso, esporte e turismo em função das praias, da infraestrutura e dos serviços ofertados.

Nos últimos anos, a orla tornou-se objeto de preocupação da comunidade e do poder público local em decorrência da erosão. A destruição atinge residências, casas comercias e ruas, de modo a comprometer parcialmente o acesso e a circulação de 
algumas áreas. Isso ganhou notoriedade através de noticiários e de redes sociais em função das perdas materiais e das mudanças no cenário paisagístico.

Porém, a erosão não ocorre de maneira uniforme, nem com a mesma intensidade ao longo da orla. Há setores mais atingidos, onde comerciantes e moradores investem em obras de contenção, como muros de arrimo, pilares de sustentação, aterros, empilhamento de sacos de areia e cimento, reforço de alicerces e de calçamentos. Algumas obras são improvisadas e desprovidas de orientação técnica, o que contribui para fragilizar a estrutura urbana diante das forças erosivas. Por outro lado, existem porções da orla pouco atingidas, onde o revestimento vegetal herbáceo das falésias, os muros de contenção e a orientação da linha de costa exercem um controle relativo diante dos agentes dinâmicos.

Pelo exposto, é possível destacar as seguintes questões: (a) como se distribuem os indicadores de erosão ao longo da orla costeira Grande-Bispo, na parte sudoeste da ilha de Mosqueiro? (b) Quais os setores mais erosivos? (c) Qual é o grau de erosão? (d) Qual deve ser a largura da orla enquanto faixa de proteção diante do grau de erosão? Com efeito, os objetivos do artigo são a caracterização morfodinâmica da orla Grande-Bispo, ilha de Mosqueiro (Belém-PA) e a identificação dos setores mais erosivos através da análise de indicadores de dinâmica costeira.

A erosão é um fenômeno físico que possui consequências socioambientais e econômicas, o que exige e justifica maior atenção da comunidade e empenho dos gestores públicos no que se refere ao ordenamento da ocupação e ao desenvolvimento local, considerando as potencialidades e as limitações de aproveitamento da orla Grande-Bispo. Isso motiva o interesse dos autores pelo tema, considerando-se, sobretudo, a importância da área estudada para o município de Belém do ponto de vista histórico, cultural e paisagístico. Assim, torna-se necessário, portanto, avaliar a situação local sob o enfoque da geomorfologia costeira para contribuir com um diagnóstico, que sirva para subsidiar a administração pública na elaboração de futuras políticas de ordenamento e de planejamento ambiental. 


\section{METODOLOGIA}

A metodologia empregada para a elaboração deste estudo reuniu etapas que abrangeram leituras teóricas, procedimentos laboratoriais e levantamentos de campo. Iniciou-se com a atualização bibliográfica sobre os conceitos que nortearam o trabalho. A definição de orla costeira e dos critérios de delimitação fundamentaramse em Christofoletti (1980), Muehe (2001) e Brasil (2002, 2004).

A aplicação do geoprocessamento na análise multitemporal da posição da linha de costa baseou-se nos trabalhos de França e Souza Filho (2003), Batista et al. (2007), Conti e Rodrigues (2011), Rodrigues e Souza Filho (2011), Silva et al. (2011), Meneses e Almeida (2012) e Ranieri e El-Robrini (2015).

A ação dos agentes costeiros, processos dinâmicos e geoindicadores foram revisados nas obras de Pinheiro (1987), Igreja et al. (1990), Muehe (1994), Coltrinari e McCall (1995), Forbes e Liverman (1996), França (2003), Souza et al. (2005), El-Robrini et al. (2006), Souza (2009); França Júnior e Villa (2011), Campos et al. (2016), Martins et al. (2016) e Brasil (2018).

Mediante a revisão dessas fontes de consulta, foi montada a seleção de indicadores que deram embasamento à análise da dinâmica costeira, sendo estes condizentes com as características da área de estudo no que se refere aos aspectos morfológicos, vegetacionais e ocupacionais: variação da posição da linha de costa (borda das falésias e promontórios), largura do arco praial, posição da linha de maré alta (LMA), largura da zona de pós-praia, largura da zona de estirâncio, presença/ausência de sistemas barra-calha, granulometria da areia praial, presença/ausência de terracetes, falésias, promontórios, plataformas de abrasão e bancos de cascalho, altura de falésias e promontórios, tipo de vegetação e condição erodida/soterrada, presença/ausência de feições erosivas/acrecionais, construções antrópicas destruídas/soterradas.

A investigação sobre a variação da posição da linha de costa, um dos indicadores físicos, foi executada em laboratório, através da análise comparativa de imagens orbitais da missão LANDSAT. Foram utilizadas duas imagens orbitais 
georreferenciadas, adquiridas gratuitamente através do sítio online da USGS Earth Explorer (United States Geological Survey): LANDSAT-5 (sensor TM) de 1984 (bandas 5, 4 e 3) e LANDSAT-8 (sensor OLI) de 2017 (bandas 6, 5 e 4), ambas da cena 223/061, resolução espacial de 30 metros.

A escolha dos anos de 1984 e 2017, com um intervalo temporal de 33 anos, ocorreu em função da média resolução das imagens. Houve necessidade de uma diferença significativa de data para que aumentasse a possibilidade de registro da mobilidade da linha de costa, considerando-se o valor do pixel nas cenas LANDSAT.

No programa ArcMap 10.1, disponível no Laboratório de Análise da Informação Geográfica da Universidade Federal do Pará (LAIG/UFPA), foi realizada a vetorização da linha de costa a partir da interpretação visual das composições coloridas do tipo "falsa cor", demarcando-se o que era interpretado como o rebordo das falésias e promontórios, bem como o contato da vegetação com a praia. Este último procedimento contou com a ajuda de um segundo produto de Sensoriamento Remoto, também gerado a partir de imagens LANDSAT: o Índice de Vegetação por Diferença Normalizada (NDVI-Normalized Difference Vegetation Index), que destaca áreas com maior, menor ou nula presença de biomassa vegetal (MENESES; ALMEIDA, 2012).

A sobreposição dos vetores permitiu a comparação da posição da linha de costa em 1984 e em 2017, o cálculo de áreas e taxas e a execução de medidas lineares, gerando dados quantitativos acerca da mobilidade temporal da mesma e da magnitude da erosão. Durante a quantificação, foram considerados os erros de georreferenciamento presentes nos metadados das imagens: 0,326 pixel para a imagem de 1984 e 0,295 pixel para a imagem de 2017. Por regra de três, calculou-se o erro de 9,7 m para a imagem de 1984 e de 8,8 m para a imagem de 2017, estabelecendo-se as margens de erro geométrico linear acumulativo $(18,6 \mathrm{~m})$ e de erro geométrico areal acumulativo $\left(559 \mathrm{~m}^{2}\right)$ entre as duas imagens.

Além das imagens do sensor TM e OLI das plataformas LANDSAT, foi também utilizada uma imagem orbital de alta resolução, disponibilizada através da aplicação Google Earth Pro, para a interpretação do relevo e delimitação da faixa de orla. 
Através deste programa, disponível gratuitamente, foi possível interpretar e vetorizar diretamente sobre a imagem as unidades morfológicas da área de estudo, com emprego da ferramenta "criação de polígonos". Procedimento semelhante foi executado para traçar os limites internos e externos da orla costeira. Neste caso, foi usada a ferramenta "criação de caminho". Em seguida, os dados foram convertidos para o formato Shapefile, editáveis no programa ArcMap 10.1, e produzidos os mapas temáticos.

Os trabalhos de campo foram realizados em maio e dezembro de 2016 e janeiro de 2019. Os procedimentos incluíram o reconhecimento das formas de relevo, leituras de azimutes e ângulos verticais, medidas de distâncias e larguras, coleta de pontos de GPS (coordenadas e elevação), registros fotográficos e o levantamento dos indicadores anteriormente selecionados.

As medidas morfométricas de campo definiram os parâmetros atribuídos a cada indicador e a subdivisão em indicadores de erosão, de estabilidade e de acumulação, desdobrando-se para um total de 95 indicadores. Produziu-se, portanto, uma lista que auxiliou a identificação e a localização dos mesmos ao longo da orla, facilitando o inventário de campo.

Pesos ou índices foram aplicados aos indicadores de erosão e de acumulação para a avaliação do grau do fenômeno dinâmico em alto (peso 3), médio (peso 2) e baixo (peso 1). Não foram atribuídos pesos aos indicadores de estabilidade. Os 95 indicadores são apresentados nos quadros 1, 2 e 3, classificados em físicos/naturais, biológicos e antropogênicos.

Quadro 1 - Indicadores de erosão adotados para análise dinâmica da orla GrandeBispo, classificados em físicos/naturais, biológicos e antropogênicos

\section{INDICADORES DE EROSÃO (FÍSICOS/NATURAIS)}

\section{PESO}

1. Largura do arco praial $<20 \mathrm{~m}$

2. Largura do arco praial de 21 a $50 \mathrm{~m}$

3. Largura do arco praial de 51 a $100 \mathrm{~m}$

4. Posição da LMA em relação à base da duna ou da falésia < $1 \mathrm{~m}$

5. Posição da LMA em relação à base da duna ou da falésia 1 a $2 \mathrm{~m}$

6. Posição da LMA em relação à base da duna ou da falésia $3 \mathrm{~m}$

7. Ausência de superfície de pós-praia/berma praial ou < 1m

\begin{tabular}{|l}
\hline 3 \\
\hline 2 \\
1 \\
\hline 3 \\
\hline 2 \\
\hline 1 \\
\hline 3 \\
\hline
\end{tabular}


8. Largura da superfície de pós-praia/berma praial 1 a $2 \mathrm{~m}$

9. Largura da superfície de pós-praia/berma praial $3 \mathrm{~m}$

10. Ausência de sistema barra/calha

11. Presença de 1 ou 2 sistemas barra/calha

12. Presença de 3 sistemas barra/calha

13. Largura da superfície de estirâncio $<20 \mathrm{~m}$

14. Largura da superfície de estirâncio entre 21 a $50 \mathrm{~m}$

15. Largura da superfície de estirâncio entre 51 e $100 \mathrm{~m}$

16. Granulometria de areia média a grossa

17. Granulometria de areia fina a média

18. Granulometria de areia fina

19. Presença de terracete ou escarpa lamosa ou arenosa próxima à

embocadura fluvial, nas superfícies de estirâncio e pós-praia ou na base das dunas (acima de 3 unidades)

20. Presença de terracete ou escarpa lamosa ou arenosa próxima à embocadura fluvial, nas superfícies de estirâncio e pós-praia ou na base das dunas ( 2 unidades)

21. Presença de terracete ou escarpa lamosa ou arenosa próxima à

embocadura fluvial, nas superfícies de estirâncio e pós-praia ou na base das dunas (1 unidade)

22. Presença de falésias ativas e promontórios além de $50 \%$ da extensão da

orla ou do setor de orla

23. Presença de falésias ativas e promontórios entre $25 \%$ e $50 \%$ da extensão da orla ou do setor de orla

24. Presença de falésias ativas e promontórios em até $25 \%$ da extensão da orla ou do setor de orla

25. Altura da falésia e do promontório $\geq 3 \mathrm{~m}$

26. Altura da falésia e do promontório de 1 a $2 \mathrm{~m}$

27. Altura da falésia e do promontório $<1 \mathrm{~m}$

28. Presença de plataforma de abrasão além de $50 \%$ da extensão da orla ou do setor de orla

29. Presença de plataforma de abrasão entre $25 \%$ e $50 \%$ da extensão da orla ou do setor de orla

30. Presença de plataforma de abrasão em até $25 \%$ da extensão da orla ou do setor de orla

31. Presença de banco de cascalho além de $50 \%$ da extensão da orla ou do setor de orla

32. Presença de banco de cascalho entre $25 \%$ e $50 \%$ da extensão da orla ou do setor de orla

33. Presença de banco de cascalho em até $25 \%$ da extensão da orla ou do setor de orla

34. Afloramento de rochas sedimentares subjacentes ao manguezal ou de sedimentos lamosos subjacentes à praia (além de $50 \%$ da extensão da orla ou do setor de orla)

35. Afloramento de rochas sedimentares subjacentes ao manguezal ou de sedimentos lamosos subjacentes à praia (entre $25 \%$ e $50 \%$ da extensão da orla ou do setor de orla)

36. Afloramento de rochas sedimentares subjacentes ao manguezal ou de sedimentos lamosos subjacentes à praia (até $25 \%$ da extensão da orla ou do setor de orla) 
37. Presença de filetes de escorrimento de água subsuperficial sobre a praia e falésia (além de $50 \%$ da extensão da orla ou do setor de orla)

38. Presença de filetes de escorrimento de água subsuperficial sobre a praia e falésia (entre $25 \%$ e $50 \%$ da extensão da orla ou de setor de orla)

39. Presença de filetes de escorrimento de água subsuperficial sobre a praia e falésia (até $25 \%$ da extensão da orla ou do setor de orla)

40. Marcas de deslizamento, desabamento e solapamento na falésia (além de 50 \% da extensão da orla ou do setor de orla)

41. Marcas de deslizamento, desabamento e solapamento na falésia (entre 25 $\%$ e $50 \%$ da extensão da orla ou do setor de orla)

42. Marcas de deslizamento, desabamento e solapamento na falésia (até $25 \%$ da extensão da orla ou do setor de orla)

INDICADORES DE EROSÃO (BIOLÓGICOS)

43. Faixa frontal de mangue, vegetação de restinga ou mata aluvial destruída pela erosão (acima de $50 \%$ da área ou do setor de orla)

44. Faixa frontal de mangue, vegetação de restinga ou mata aluvial destruída pela erosão (entre $25 \%$ e $50 \%$ da área ou do setor de orla)

45. Faixa frontal de mangue, vegetação de restinga ou mata aluvial destruída pela erosão (até $25 \%$ da área ou do setor de orla)

46. Presença de vegetação de terra firme no arco praial (acima de $50 \%$ da praia)

47. Presença de vegetação de terra firme no arco praial (entre $25 \%$ e $50 \%$ da praia)

48. Presença de vegetação de terra firme no arco praial (até $25 \%$ da praia) INDICADORES DE EROSÃO (ANTROPOGÊNICOS)

49. Construção e via situada na margem superior da falésia ou da praia com mais de $50 \%$ de destruição por agentes físicos

50. Construção e via situada na margem superior da falésia ou da praia com 25 $\%$ a $50 \%$ de destruição por agentes físicos

51. Construção e via situada na margem superior da falésia ou da praia com até $25 \%$ de destruição por agentes físicos

52. Tubulação de água ou de esgoto, situada na margem superior, média ou inferior da falésia ativa, em situação de destruição por agentes físicos (acima de 4 unidades)

53. Tubulação de água ou de esgoto, situada na margem superior, média ou inferior da falésia ativa, em situação de destruição por agentes físicos (3 a 4 unidades)

54. Tubulação de água ou de esgoto, situada na margem superior, média ou inferior da falésia ativa, em situação de destruição por agentes físicos (até 2 unidades)

55. Presença de muros de arrimo e outras construções na base das falésias ativas ou isolados na superfície de estirâncio (acima de 4 unidades)

56. Presença de muros de arrimo e outras construções na base das falésias ativas ou isolados na superfície de estirâncio (3 a 4 unidades)

57. Presença de muros de arrimo e outras construções na base das falésias ativas ou isolados na superfície de estirâncio (até 2 unidades)

58. Alicerces, sapatas, pilares e vigas expostos devido à remoção de areia praial por ação das ondas (acima de $50 \%$ da extensão da orla ou do setor de orla)

59. Alicerces, sapatas, pilares e vigas expostos devido à remoção de areia praial por ação das ondas (entre $25 \%$ e $50 \%$ da extensão da orla ou do setor de orla)

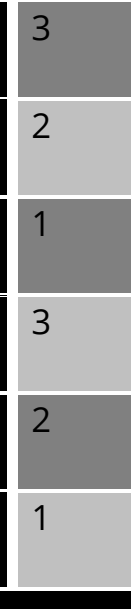


60. Alicerces, sapatas, pilares e vigas expostos devido à remoção de areia praial

por ação das ondas (até $25 \%$ da extensão da orla ou do setor de orla)

Fonte: Ferreira Júnior e França (2016); Silva e França (2016); Neves et al. (2019)

Quadro 2 - Indicadores de estabilidade com os parâmetros adotados para a análise dinâmica da orla Grande-Bispo

\begin{tabular}{l} 
INDICADORES DE ACUMULAÇÃO ( FÍSICOS/NATURAIS) \\
66. Largura do arco praial > $250 \mathrm{~m}$ \\
\hline 67. Largura do arco praial de 201 a $250 \mathrm{~m}$ \\
\hline 68. Largura do arco praial 150 a $200 \mathrm{~m}$ \\
\hline 69. Posição da LMA em relação à base da duna ou da falésia > $8 \mathrm{~m}$ \\
\hline 70. Posição da LMA em relação à base da duna ou da falésia 7 e $8 \mathrm{~m}$ \\
\hline 71. Posição da LMA em relação à base da duna ou da falésia 5 e $6 \mathrm{~m}$ \\
\hline 72. Largura da superfície de pós-praia/berma praial >8 m \\
\hline 73. Largura da superfície de pós-praia/berma praial 7 e $8 \mathrm{~m}$ \\
\hline 74. Largura da superfície de pós-praia/berma praial 5 e $6 \mathrm{~m}$ \\
\hline 75. Presença de 6 ou mais sistemas barra/calha \\
\hline 76. Presença de 5 sistemas barra/calha \\
\hline 77. Presença de 4 sistemas barra/calha \\
\hline 78. Largura da superfície de estirâncio $>250 \mathrm{~m}$ \\
\hline 79. Largura da superfície de estirâncio entre 201 e $250 \mathrm{~m}$ \\
\hline 80. Largura da superfície de estirâncio 150 a $200 \mathrm{~m}$ \\
\hline 81. Granulometria de areia fina \\
\hline 82. Granulometria de areia fina a média \\
\hline 83. Granulometria de areia média a grossa \\
\hline 84. Presença de zona de retenção ou faixa de acreção arenosa ou lamosa por \\
influência de embocadura fluvial de baixa hierarquia (ocupa acima de $50 \%$ da \\
área considerada) \\
\hline 85. Presenca de
\end{tabular}

85. Presença de zona de retenção ou faixa de acreção arenosa ou lamosa por influência de embocadura fluvial de baixa hierarquia (ocupa entre 25 \% e 50 \% da área considerada)

86. Presença de zona de retenção ou faixa de acreção arenosa ou lamosa por influência de embocadura fluvial de baixa hierarquia (ocupa até $25 \%$ da área considerada)

INDICADORES DE ACUMULAÇÃO (BIOLÓGICOS)

87. Presença de vegetação de mangue sobre superfície de estirâncio e/ou banco lamoso no interior de estuários, canais de maré ou lagunas (acima de 50 \% da área)

88. Presença de vegetação de mangue sobre superfície de estirâncio e/ou banco lamoso no interior de estuários, canais de maré ou lagunas (entre $25 \%$ e 50 \% da área)

89. Presença de vegetação de mangue sobre superfície de estirâncio e/ou banco lamoso no interior de estuários, canais de maré ou lagunas (em até $25 \%$ da área) INDICADORES DE ACUMULAÇÃO ( ANTROPOGÊNICOS)

90. Zona de retenção ou acreção arenosa ou lamosa por influência de construção perpendicular à linha de costa (acima de 50 \% da extensão da orla ou do setor de orla)

\section{PESO}

3

2

1
3

2

1

3

2

1

3

2

1

3

2

1

3

2

1

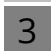

2

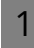

1
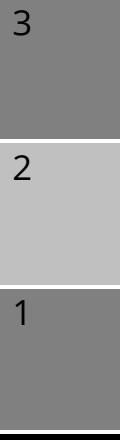

3

2$$
2
$$

SO an 
91. Zona de retenção ou acreção arenosa ou lamosa por influência de construção perpendicular à linha de costa (entre $25 \%$ e $50 \%$ da extensão da orla ou do setor de orla)

92. Zona de retenção ou acreção arenosa ou lamosa por influência de construção perpendicular à linha de costa (até $25 \%$ da extensão da orla ou do setor de orla)

93. Construções ou vias de circulação soterradas por areias dunares ou praiais ou por lama de manguezal (acima de 50 \% da extensão da orla ou do setor de orla)

94. Construções ou vias de circulação soterradas por areias dunares ou praiais ou por lama de manguezal (entre $25 \%$ e 50 \% da extensão da orla ou do setor de orla)

95. Construções ou vias de circulação soterradas por areias dunares ou praiais ou por lama de manguezal (até $25 \%$ da extensão da orla ou do setor de orla)

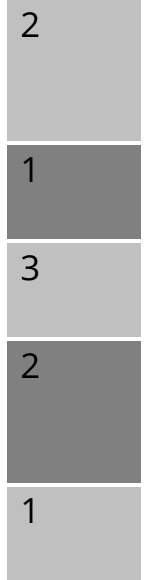

Fonte: Ferreira Júnior e França (2016); Silva e França (2016); Neves et al. (2019)

Quadro 3 - Indicadores de acumulação adotados para a análise dinâmica da orla Grande-Bispo, classificados em físicos/naturais, biológicos e antropogênicos

\section{INDICADORES DE ESTABILIDADE}

61. Largura do arco praial entre 100 e $150 \mathrm{~m}$

62. Posição da linha de maré alta entre 4 e $5 \mathrm{~m}$ em relação à base da duna ou da falésia

63. Largura da superfície de pós-praia/berma praial 4 e $5 \mathrm{~m}$

64. Largura da superfície de estirâncio entre 101 a $150 \mathrm{~m}$

65. Presença de vegetação arbórea, arbustiva ou herbácea, antropogênica ou

não, sobre pós-praia/berma, planície alagável ou falésia, recobrindo, no mínimo $50 \%$ da extensão da orla ou setor de orla

Fonte: Ferreira Júnior e França (2016); Silva e França (2016); Neves et al. (2019)

O cruzamento dos dados de laboratório e de campo permitiu a compartimentação taxonômica do relevo, a delimitação da orla, a análise da distribuição dos indicadores, a identificação de áreas progradacionais e retrogradacionais e a classificação do grau de dinâmica costeira. Esses resultados foram representados através de produtos cartográficos.

\section{RESULTADOS}

\subsection{O uso de indicadores na análise da dinâmica costeira no estado do pará}

Nos estudos sobre dinâmica costeira, há forte preocupação com os enfoques voltados para o diagnóstico das modificações do meio físico, induzidas por processos de erosão e de sedimentação. Neste aspecto, a dinâmica costeira consiste num 
conjunto de mudanças no relevo, na cobertura vegetal e nos solos enquanto respostas à ação de agentes, tais como as marés, ondas, correntes e ventos. Esses estudos podem envolver períodos temporais de centenas a milhares de anos, ou podem limitar-se às mudanças atuais, relativas às últimas décadas.

Os trabalhos de França e Souza Filho (2003), El-Robrini et al. (2006), Batista et al. (2007), Souza (2009), França Júnior e Villa (2011), Rodrigues e Souza Filho (2011), Silva et al. (2011), Ranieri e El-Robrini (2015), Campos et al. (2016) e Martins et al. (2016) demonstram que a análise da dinâmica costeira baseia-se em três principais abordagens: (a) no monitoramento da posição da linha de costa; (b) no levantamento de indicadores de erosão e sedimentação; e (c) na morfodinâmica praial.

Souza (2009) comenta como alguns fatores meteorológicos/climáticos exercem influência no nível do mar, na atuação dos ventos, no regime de ondas e correntes. Com efeito, interferem nos fenômenos de erosão e deposição, que modificam a configuração costeira. Isso significa que, ao longo dos anos, a linha de costa sofre variações em sua posição. Pode ocorrer deslocamento da mesma na direção do interior do continente, processo considerado como recuo ou retrogradação devido à perda sedimentar. Nessas circunstâncias, surgem falésias, plataformas de abrasão, terraços, além da redução na largura de praias e campos de duna.

Ao contrário, nos casos em que há crescimento de formas litorâneas, como deltas, restingas e planícies de maré, pela deposição ou acúmulo de sedimentos, a linha de costa avança na direção do mar, o que resulta em progradação de áreas costeiras. Assim, a mobilidade da linha de costa implica, necessariamente, em mudanças morfológicas.

A posição da linha de costa pode ser monitorada através de imagens de satélite e radar, dentro de uma escala temporal, como forma de determinação da tendência evolutiva em médio prazo de qualquer trecho das regiões litorâneas, analisando os movimentos de progradação (como resultantes de acumulação ou de acreção sedimentar), de retrogradação (como resposta à erosão) ou de estabilidade da posição da linha de costa. 
O levantamento da distribuição espacial de indicadores atuais é realizado através de inventários de campo. Consiste na identificação e localização das evidências físicas (geoindicadores), biológicas (bioindicadores) e antrópicas da erosão e da acreção sedimentar enquanto registros das modificações ambientais de curto prazo, dentro de uma escala anual ou sazonal.

Por fim, a análise da morfodinâmica praial inclui o monitoramento de perfis topográficos e do regime de ondas para classificar as praias de acordo com o comportamento do tipo dissipativo, reflexivo ou intermediário. Neste caso, o estado morfodinâmico reflete o conjunto de propriedades físicas da praia, suas formas deposicionais e sua relação com a hidrodinâmica local.

As evidências que atestam a dinâmica costeira são tratadas como elementos indicadores, dentre os quais se distinguem os naturais (físicos e biológicos) e os que são originados sob interferência antrópica. Os geoindicadores são parâmetros de magnitudes, frequências, taxas e tendências relacionadas aos processos ou eventos geológicos com ocorrência de até 100 anos. Eles refletem variações físicas que contribuem para a análise de mudanças de médio ou de curto período, podendo ser utilizados para a elaboração de diagnósticos e prognósticos, considerando-se as peculiaridades geológico-geomorfológicas das áreas estudadas (COLTRINARI; McCALL, 1995; FRANÇA JÚNIOR; VILLA, 2011).

Um dos mais importantes indicadores de dinâmica costeira é a linha de costa, que pode ser definida por meio de vários critérios, tais como, a linha d'água no instante do levantamento de campo, a linha da preamar de sizígia, o limite da vegetação, o limite terrestre da sedimentação de leques de lavagem em lagunas e estuários, a base ou o topo de falésias, dentre outros (FORBES; LIVERMAN, 1996).

No que tange ao estudo sobre a posição da linha de costa, foram feitos diversos trabalhos no Pará com o objetivo de identificar, monitorar, mapear e comparar áreas sujeitas a recuo e acreção. Para alcançar tais objetivos, as técnicas e recursos do Sensoriamento Remoto e do Geoprocessamento mostraram-se de suma importância para análises qualitativas e quantitativas das regiões costeiras. Dessa 
forma, o uso de imagens de Sensoriamento Remoto de diferentes épocas serve para a comparação das posições da linha de costa ao longo de um determinado intervalo de tempo.

Dentre esses trabalhos, podem ser citados os de França e Souza Filho (2003) que constataram o predomínio de erosão, na margem leste da ilha de Marajó, entre 1986 e 2001. Durante esses 15 anos, as taxas de recuo da linha de costa foram maiores no município de Soure, alcançando valores de 21 m/ano, 39 m/ano e 185 m/ano, o que resultou na destruição da franja de manguezais, migração de depósitos praia-duna para o interior e formação de terraços lamosos. Porém, houve a presença de setores progradacionais, onde a linha de costa avançou em taxas que variaram de 16 a 109 m/ano.

Rodrigues e Souza Filho (2011) analisaram a variação da linha de costa no município de Curuçá, em um período de 24 anos. As áreas submetidas à erosão foram maiores do que as que sofreram acreção, chegando a $82 \%$ da área total submetida à dinâmica costeira. Os setores retrogradacionais somaram $2,1 \mathrm{~km}^{2}$ (entre 1984 e 2001), 6,8 km² (de 2001 a 2004) e 1,9 km² (de 2004 a 2008), no entorno das baías de Curuçá e Marajó. O avanço da linha de costa alcançou taxas entre 42 e 147 m/ano, enquanto que o recuo apresentou taxas que variaram de 43 a 67 m/ano.

Outra relevante contribuição acerca do uso da linha de costa como geoindicador de dinâmica costeira foi o artigo de Conti e Rodrigues (2011) sobre a ilha dos Guarás, também no município de Curuçá. Os autores caracterizaram três setores com dinâmicas variadas no que tange à variação da linha de costa, entre os anos de 1973 e 2011. A ponta da Romana, setor ocidental da ilha, destacou-se por expressivo avanço da linha de costa, que alcançou 1.300 m entre 1973 e 2011, com taxa média de 35 m/ano. Isso resultou na formação de sucessivos cordões arenosos praiais com crescimento na direção oeste. O setor centro-norte da ilha caracterizou-se pela sucessão de fase de acreção, de erosão e, mais recentemente, de estabilidade. E o setor oriental mostrou um lento processo de progradação. 
Ranieri e El-Robrini (2015) fizeram uso das taxas médias de variação da linha de costa para explicar a dinâmica sedimentar predominante no município de Salinópolis. Os dados sobre a variação da linha de costa foram obtidos através de imagens orbitais de plataformas LANDSAT, em um recorte temporal de 25 anos. 0 estudo acusou uma tendência progradacional com taxas anuais desde 0,06 m/ano até 18,24 m/ano, entre 1988 e 2013. Entretanto, houve retrogradação em setores restritos, tais como nas divisas das praias Corvina-Maçarico e Farol Velho-Atalaia, consideradas como áreas mais vulneráveis às ações do oceano. A taxa de recuo da linha de costa alcançou a média de 1,62 m/ano. Coincidentemente, estes setores correspondem à parte mais urbanizada e, portanto, mais impactada. Os efeitos da erosão refletiram-se na perda parcial de moradias e estabelecimentos comerciais, bem como na destruição de vias de acesso às praias.

Pelo exposto, a dinâmica costeira é o conjunto de mudanças de ordem erosiva e/ou acumulativa, que expressa a ininterrupta relação entre os agentes costeiros, ligados principalmente à ação das ondas, marés, ventos, correntes e chuvas, o que implica na destruição ou reconstrução do relevo costeiro, dos solos e da cobertura vegetal. É registrada e avaliada por meio de indicadores, considerados como evidências dessas modificações (FRANÇA; SOUZA FILHO, 2003). Os agentes costeiros atuam ininterruptamente sobre os materiais da costa e deixam vestígios ou testemunhos, que podem ser utilizados para determinar qual processo morfológico predomina em determinada área.

O arcabouço teórico-metodológico da literatura revisada serviu de base para o estudo da dinâmica costeira da área na presente pesquisa, chamada orla GrandeBispo. A análise dos indicadores pautou-se em dois procedimentos: (a) interpretação de imagens orbitais com intervalo temporal de 33 anos; e (b) levantamento de campo.

\subsection{Variação temporal da Linha de Costa Grande-Bispo, llha de Mosqueiro, Belém-PA}

A comparação da posição da linha de costa, entre as imagens dos anos de 1984 e de 2017, revelou que na orla Grande, houve um recuo médio de 32 m ( \pm 18,6 
m, considerando o erro acumulativo das imagens para medidas lineares) com taxa de 0,9 m/ano. As áreas retrogradacionais totalizaram $13.500 \mathrm{~m}^{2}\left( \pm\right.$ de $559 \mathrm{~m}^{2}$, considerando o erro acumulativo das imagens para medidas areolares), correspondendo a 70\% dos setores submetidos à dinâmica costeira.

O predomínio da erosão justifica-se pela ocorrência dos seguintes elementos: (a) falésias constituídas, no seu perfil superior, de material sedimentar areno-argiloso e margeadas por vias de circulação de automóveis; (b) posição geográfica sujeita à ação de mesomarés; (c) orientação NE-SW, facilitando a influência das ondas que se deslocam de norte para sul, na baía de Marajó, e que podem atingir de 1 a 1,5 m de altura, nos meses de ventos mais fortes; e (d) infraestrutura urbana com rede de microdrenagem inadequada ou sem manutenção, possibilitando o escoamento livre das águas pluviais que atingem facilmente a borda das falésias. Trata-se de um cenário propício a processos erosivos em razão da conjugação de fatores físicos e sociais.

Apesar do predomínio da erosão, verificou-se progradação da linha de costa na extremidade norte da orla Grande. Isso se justifica pela orientação NW-SE da costa e presença de ambientes mais calmos do ponto de vista hidrodinâmico, localizados no interior de enseadas ao abrigo de promontórios. Nesses locais, entre 1984 e 2017, ocorreu crescimento de barras lamosas, seguida de colonização por vegetação herbácea e arbustiva. Além disso, houve adensamento da cobertura arbustivoarbórea desde o rebordo das falésias até a porção superior da praia. Este último aspecto pode estar relacionado a uma redução da pressão antrópica devido à ausência de novas construções. As áreas acrescidas somaram $5.700 \mathrm{~m}^{2} \pm$ de $559 \mathrm{~m}^{2}$, com avanço linear médio de $27 \mathrm{~m} \pm 18,6 \mathrm{~m}$ e taxa de 0,8 m/ano (Figura 2).

Na orla do Bispo, a erosão das falésias ocorreu em locais restritos, com taxa de 0,7 m/ano. Nesses setores, o recuo linear médio do rebordo das falésias chegou a 24 $m$ ( $\pm 18,6 \mathrm{~m}$, considerando o erro acumulativo das imagens para medidas lineares). A área submetida à erosão alcançou $900 \mathrm{~m}^{2}$ ( \pm de $559 \mathrm{~m}^{2}$, considerando o erro acumulativo das imagens para medidas areolares), com taxa de erosão de $27 \mathrm{~m}^{2} / a n o$ 
Figura 2 - Variação da posição da linha de costa na orla Grande, em 1984 e 2017, e áreas progradacionais e retrogradacionais.

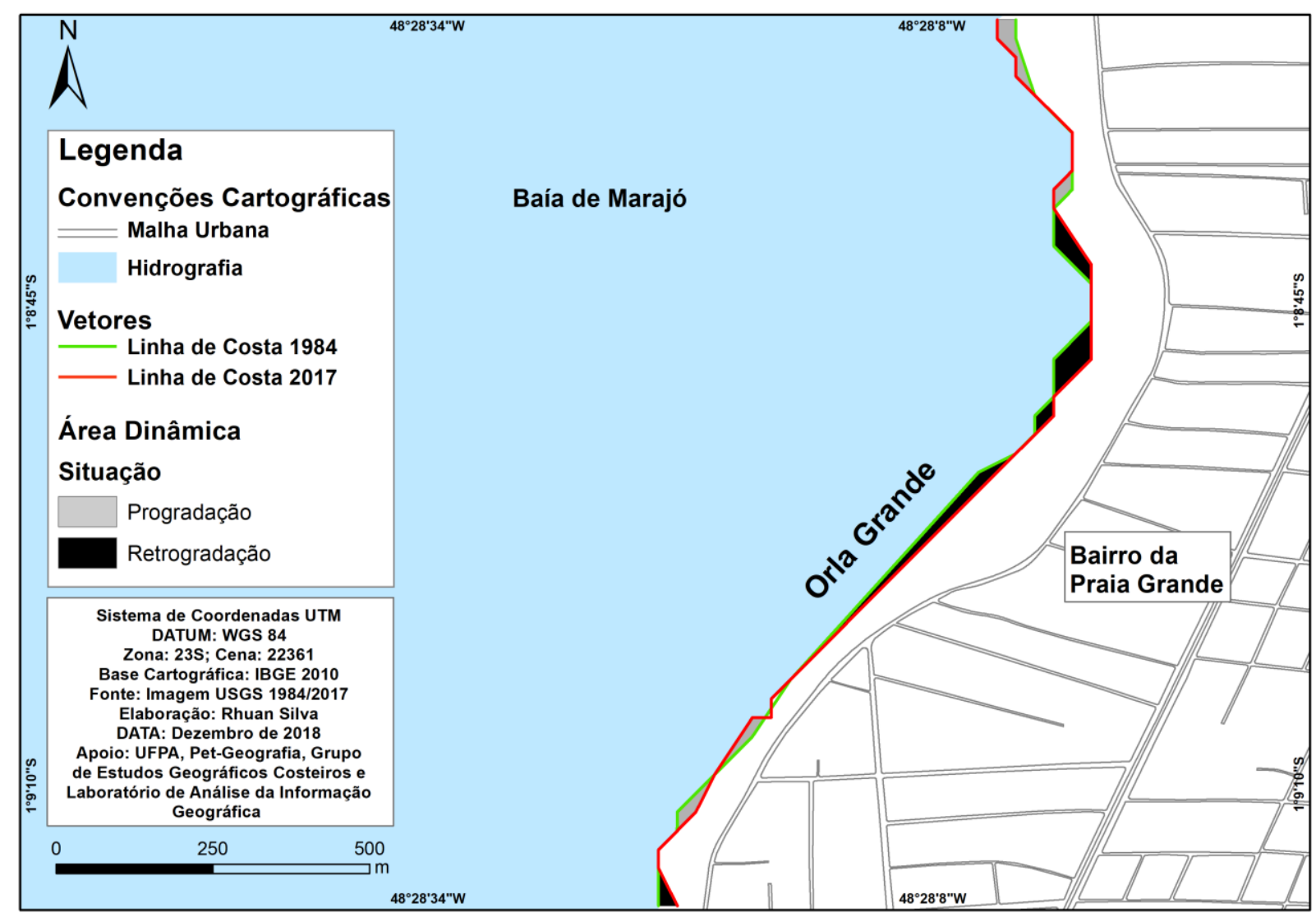

Organização dos autores (2018).

Na maior parte do Bispo, a linha de costa mostrou-se estável durante o período 1984-2017, o que está relacionado a fatores vinculados às condições do meio físico e às características da ocupação, destacando-se: (a) promontórios e falésias constituídos por arenitos mais resistentes à erosão; (b) em algumas áreas, a presença de um campo de matacões de dimensões métricas, que se distribui pelo flanco e sopé das falésias, exerce proteção à linha de costa diante do ataque das ondas; e (c) revestimento das falésias por vegetação herbácea de cobertura contínua e por obras de engenharia, tais como muros de arrimo em concreto, rampas e patamares aterrados e asfaltados (Figura 3). 
Figura 3 - Variação da posição da linha de costa na orla do Bispo, em 1984 e 2017, e áreas retrogradacionais.

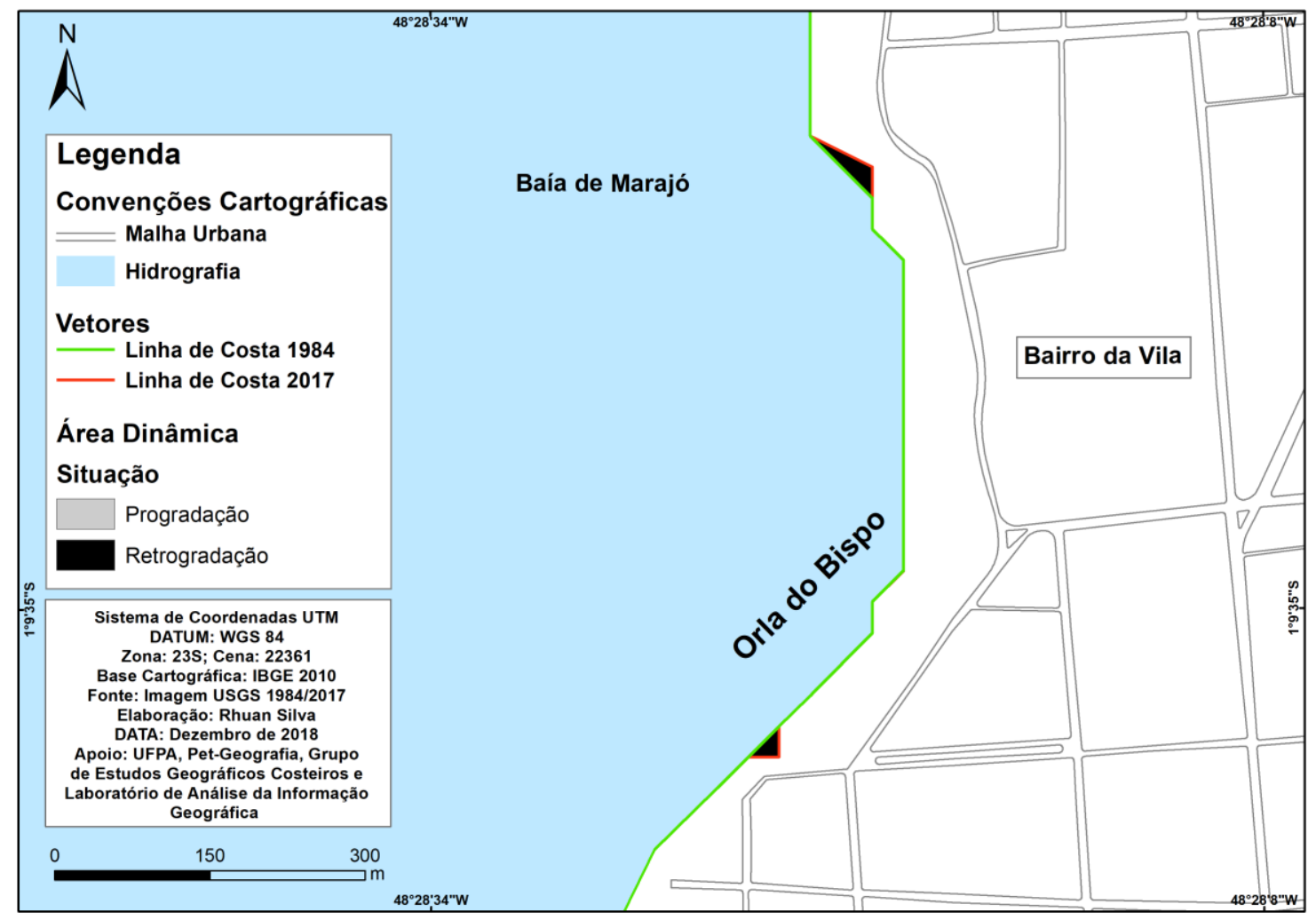

Organização dos autores (2018).

Ao relacionar esses valores de mobilidade da linha de costa com os dados referentes aos municípios de Soure e Salvaterra (FRANÇA; SOUZA FILHO, 2003) e Curuçá (RODRIGUES; SOUZA FILHO, 2011), é possível estabelecer os parâmetros que definem o grau da dinâmica. Tendo-se como indicador a variação da posição da linha de costa, considera-se como base de cálculo a taxa média de mobilidade máxima da linha de costa (avanço e recuo), no setor costeiro do Pará compreendido entre os municípios de Soure e Salvaterra (margem esquerda da baía de Marajó), orla GrandeBispo (margem direita da baía de Marajó) e Curuçá (costa atlântica), que é de 53 m/ano. Assim, os graus de intensidade do fenômeno dinâmico de acumulação ou de erosão são determinados pelos seguintes parâmetros e pesos: (a) taxa anual inferior a 35,3 m/ano caracteriza baixo grau; (b) taxa anual de 35,3 a 70,7 m/ano indica médio grau; e (c) taxa anual superior a 70,7 m/ano aponta alto grau. 
Com efeito, as medidas de magnitudes e taxas mostram um comportamento diferenciado ao longo da área estudada, numa escala temporal de médio período. A orla Grande apresentou predomínio da retrogradação de baixo grau de intensidade, com taxas bem inferiores a 35,3 m/ano, enquanto a orla do Bispo mostrou uma situação de estabilidade da linha de costa. Os resultados dessa análise multitemporal podem ser refinados com a utilização de imagens de alta resolução.

\subsection{Delimitação e caracterização morfológica da Orla Grande-Bispo}

Muehe (2001) conceitua orla como uma faixa de proteção dentro da zona costeira, cuja delimitação é definida de acordo com as características físicas, biológicas e antrópicas da costa. Está relacionada diretamente à conservação do ambiente e dos recursos, diante de uma possível subida do nível do mar, nos próximos cem anos. A concepção de orla vem ao encontro da necessidade de planejamento do uso e ocupação face à dinâmica da zona costeira.

A erosão e a sedimentação influenciam na definição da largura dessa faixa de proteção. Nesse sentido, Muehe (2001) propõe os critérios geomorfológicos para a fixação dos marcos oceânicos e terrestres da orla: a profundidade de fechamento do perfil e o tipo de relevo costeiro. Além desses, adota as formas de apropriação dos recursos naturais pela ação humana.

O limite externo (oceânico) da orla inicia-se no ponto de profundidade de fechamento de perfil, local máximo em que as ondas da superfície do mar, que se aproximam da costa, mobilizam os sedimentos do fundo. Na costa brasileira, este local é marcado pelas profundidades entre 5 e 10 m (MUEHE, 2001). O limite interno (terrestre) depende das características morfológicas e da ocupação humana.

Diante disso, são propostos os seguintes critérios com base na fisiografia: para falésias sedimentares ocupadas pelo uso urbano, limite de $50 \mathrm{~m}$ contados a partir da borda superior das mesmas; para falésias sedimentares não urbanizadas, limite de $200 \mathrm{~m}$ a partir do rebordo para o interior do continente; para falésias de rochas cristalinas, $1 \mathrm{~m}$ além do limite máximo de alcance das ondas de tempestade; para 
áreas inundáveis, cota topográfica de $1 \mathrm{~m}$ além do limite máximo alcançado pela maré de sizígia; para praias e dunas urbanizadas, $50 \mathrm{~m}$ a partir do limite da praia ou do reverso da duna; para praias e dunas não urbanizadas, de ocupação não consolidada e de ocupação rural, 200 m a partir do limite da praia ou do reverso da duna. Tais limites podem ser alterados de acordo com estudos sobre tendências erosivas que ultrapassem os limites propostos (MUEHE, 2001).

Conforme a escala de trabalho e a divisão taxonômica do relevo proposta por Ross (1992), a área compartimenta-se em duas unidades de 4 . $^{\circ}$ táxon: praia de enseada e baixo platô. As praias Grande e do Bispo estendem-se como cordões arenosos de geometria retilínea a côncava, alojados nas reentrâncias contornadas por falésias e seccionadas por promontórios. A gênese dessas praias está relacionada aos processos acumulativos atuais, resultantes da hidrodinâmica da baía de Marajó.

O baixo platô possui superfície aplainada a suavemente ondulada cujas cotas variam de 5 a $15 \mathrm{~m}$. Trata-se de um planalto de estrutura sedimentar, composto pelos argilitos, arenitos, conglomerados e sedimentos areno-argilosos do Grupo BarreirasPós-Barreiras, do Mioceno ao Holoceno Inferior (ROSSETTI, 2001). Na zona de contato com as praias, apresenta rebordo escarpado e anguloso definido por falésias e promontórios (5. ${ }^{\circ}$ táxon). Os processos de intemperismo e erosão das falésias e promontórios originam, em alguns setores, a ocorrência de campo de matacões e plataforma de abrasão (Quadro 4; Figuras 4 e 5).

Quadro 4 - Divisão taxonômica do relevo da orla Grande-Bispo

\begin{tabular}{|c|c|c|}
\hline $\begin{array}{l}\text { TIPOS DE FORMAS DE } \\
\text { RELEVO (4. }{ }^{\circ} \text { TÁXON) }\end{array}$ & $\begin{array}{l}\text { SUBDIVISÃO DE } 5 .^{\circ} \\
\text { TÁXON }\end{array}$ & $\begin{array}{l}\text { FORMAS LINEARES E AREOLARES } \\
\qquad\left(6 .^{\circ} \mathrm{TÁXON}\right)\end{array}$ \\
\hline Praia de enseada & $\begin{array}{c}\text { Superfície de pós-praia } \\
\text { Superfície de estirâncio } \\
\text { Banco de cascalho }\end{array}$ & $\begin{array}{l}\text { Filete de escoamento de água } \\
\text { subsuperficial }\end{array}$ \\
\hline Baixo platô & $\begin{array}{c}\text { Falésia } \\
\text { Promontório } \\
\text { Plataforma de abrasão } \\
\text { Campo de matacões }\end{array}$ & $\begin{array}{l}\text { Duto de escoamento de água } \\
\text { subsuperficial } \\
\text { Sulco de escoamento de água } \\
\text { pluvial ou de efluente urbano } \\
\text { Marmita de dissolução } \\
\text { Marca de deslizamento, } \\
\text { desabamento e solapamento }\end{array}$ \\
\hline
\end{tabular}

Organização dos autores 
Figura 4 - Compartimentação morfológica e delimitação da orla Grande

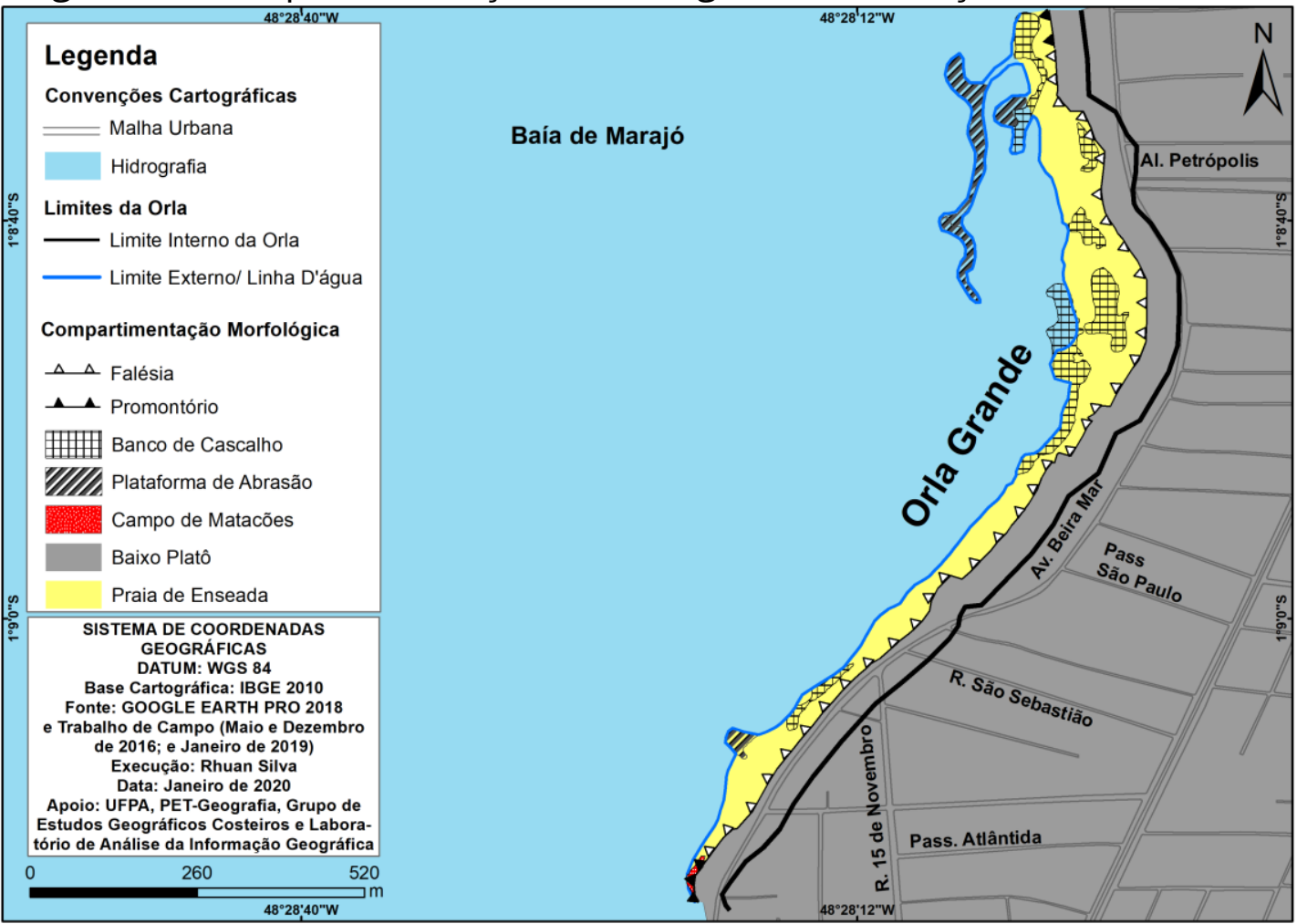

Organização dos autores (2020)

Figura 5 - Compartimentação morfológica e delimitação da orla do Bispo

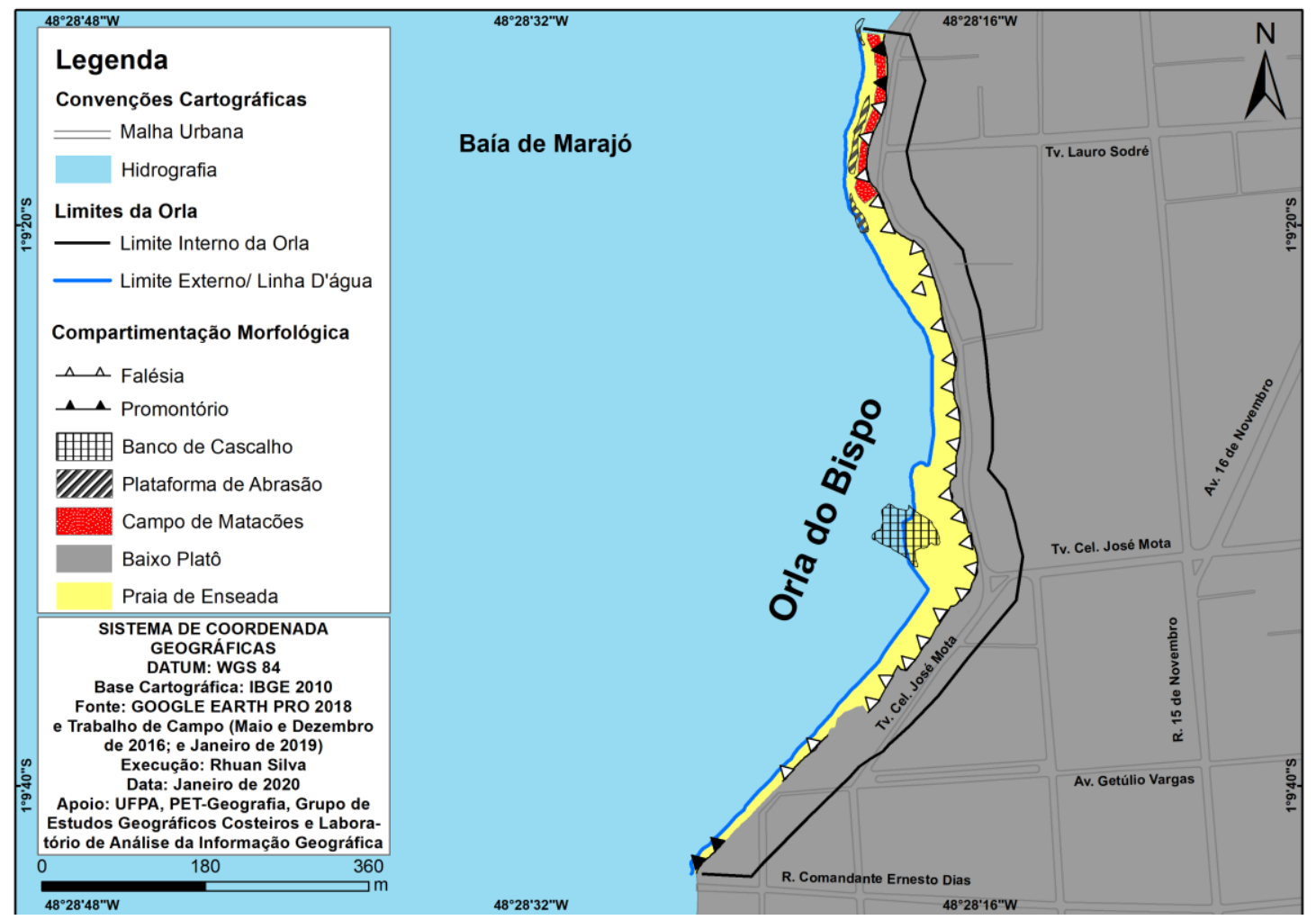

Organização dos autores (2020) 
Para a demarcação da orla Grande-Bispo, os limites foram definidos considerando os seguintes elementos: (a) os critérios morfológicos e topográficos estabelecidos por Muehe (2001); (b) a compartimentação do relevo; e (c) as taxas de variação da linha de costa entre 1984 e 2017.

Para o limite interno da orla Grande-Bispo, definiu-se o marco de 50 m, cuja medida iniciou-se na beira das falésias e estendeu-se na direção do interior, seguindo a superfície aplainada do baixo platô. Justifica-se esta demarcação pelas características ligadas ao relevo, à estrutura sedimentar, à ocupação, à estabilidade e à baixa taxa de erosão da linha de costa.

Quando à definição do limite externo, é necessário fazer uma ressalva: a insuficiência de dados batimétricos e hidrodinâmicos sobre a baía de Marajó, em escala de detalhe, dificultou a demarcação. Diante disso, optou-se pela linha d'água identificada nas imagens e nos trabalhos de campo, adotando-se esta linha como marco inicial para a fixação do limite externo para a orla estudada.

Ao se estabelecer a demarcação dos limites da orla Grande-Bispo, verifica-se que a mesma configura-se como um polígono irregular cujas dimensões variam de 50 m, nas partes mais estreitas, a 170 m, nas porções mais largas.

\section{4 distribuição espacial dos indicadores dinâmicos atuais na Orla Grande-Bispo}

Dentre os 95 indicadores selecionados para a análise, 33 foram identificados e localizados durante os levantamentos de campo ao longo da orla Grande-Bispo: 31 de erosão, 1 de estabilidade e 1 de acumulação, atestando, desse modo, o predomínio do fenômeno erosivo. Esses indicadores refletiram modificações de curto período e deram embasamento para a caracterização da orla e dos subsetores quanto ao grau do fenômeno dinâmico.

A distribuição espacial dos indicadores permitiu a divisão da orla Grande em dois subsetores: norte e centro-sul. No norte, que apresenta uma extensão de aproximadamente 650 m e uma largura entre 100 e 170 m, estão localizados 17 
indicadores de erosão dos quais 7 têm peso 3. Isto é, $41 \%$ atestam erosão de alto grau.

No centro-sul, com extensão de aproximadamente $1.200 \mathrm{~m}$ e largura entre 60 e $150 \mathrm{~m}$, foram registrados 18 indicadores de erosão, sendo 11 de peso 2. Ou seja, 61\% definem erosão de médio grau para este subsetor (Figura 6).

Figura 6 - Distribuição espacial dos indicadores dinâmicos na orla Grande

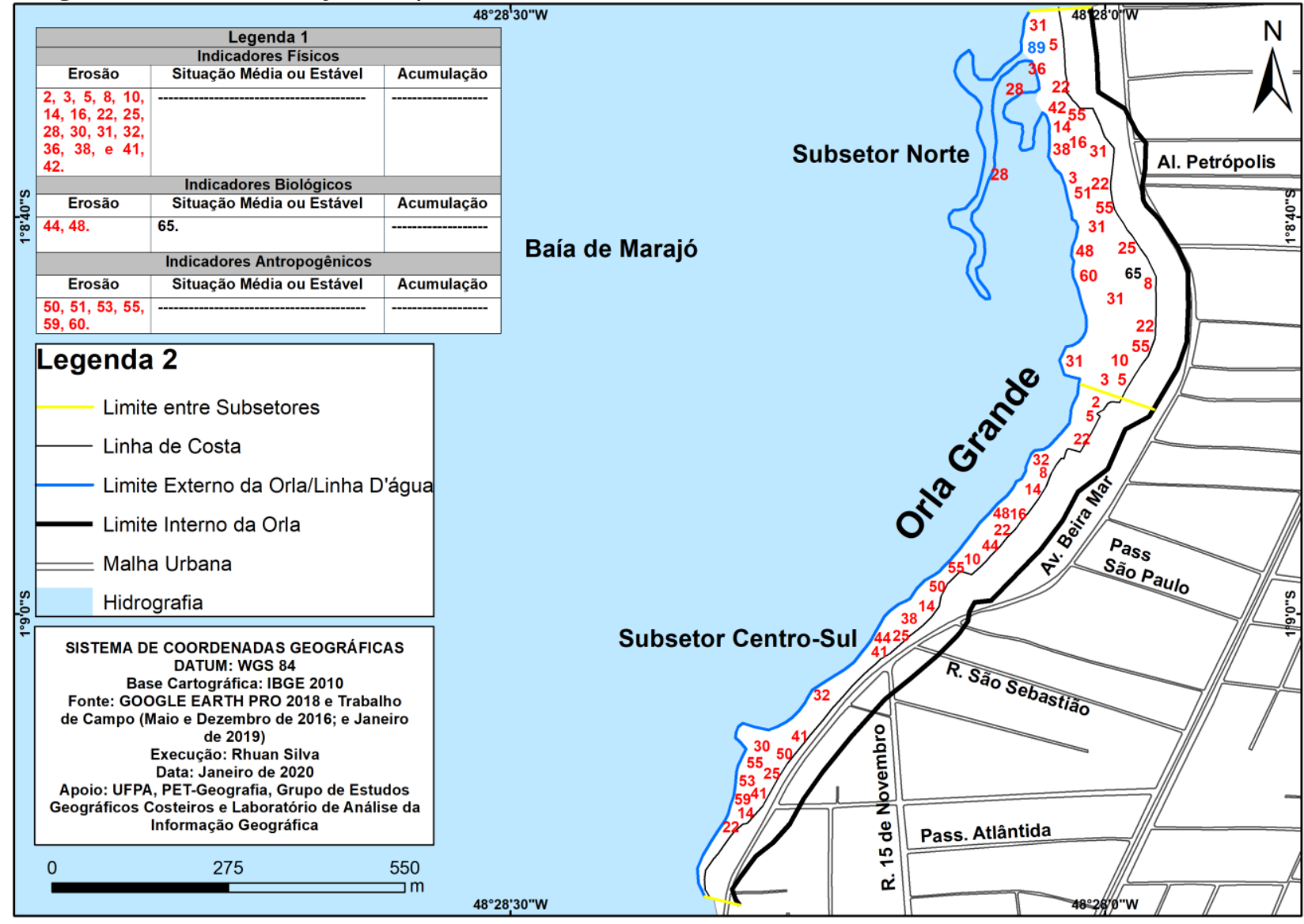

Organização dos autores (2020)

No norte da orla Grande, os indicadores de alta erosão ratificam características morfológicas marcadas por falésias ativas e promontórios com altura igual ou superior a 3 m, que guarnecem toda a extensão da linha de costa. Além das falésias, as plataformas de abrasão e os bancos de cascalho estendem-se por mais de 50\% do subsetor. A praia é constituída por areias médias a grossas e não possui sistema barra/calha. Muros de arrimo são construídos na base das escarpas, enquanto que outros se encontram tombados ou isolados na zona de estirâncio da praia. 
No setor centro-sul, o médio grau de erosão expressa-se pelas seguintes características morfométricas: o arco praial tem largura entre 21 e 50 m, enquanto a superfície de pós-praia pode alcançar de 1 a 2 m em função do posicionamento da linha de maré alta próximo da base das falésias. Estas exibem marcas de deslizamento e desabamento ou solapamento por ondas.

A erosão dos arenitos alimenta a formação de bancos de cascalho, amplamente distribuídos ao longo da praia, chegando a ocupar uma extensão relativa de $25 \%$ a $50 \%$ do subsetor. Feições erosivas lineares (filetes de escorrimento de água subsuperficial) desenvolvem-se no flanco das escarpas e na praia. Juntam-se a esses elementos o tombamento de árvores e arbustos, a destruição de arruamentos e de estabelecimentos comerciais ou residenciais. Em boa parte da área (25\% a 50\%), estruturas de sustentação, como alicerces, sapatas, pilares e vigas tornam-se expostos devido à remoção de sedimentos e rochas por ação de marés e ondas (Figura 7).

Face à gravidade do fenômeno erosivo, a parte centro-sul da orla Grande foi uma das áreas da ilha de Mosqueiro contempladas com obras de intervenção urbana, nos anos de 2017 e 2018. O projeto foi financiado pelo Ministério da Integração Nacional em parceria com a Prefeitura Municipal de Belém. Incluiu a reconstrução de via pública, calçadas, de muro de contenção, rampas de acesso e iluminação pública (AGÊNCIA BELÉM, 2017).

A orla do Bispo possui extensão de 1.100 m e largura entre 50 e 170 m, onde foram registrados 18 indicadores de erosão, dos quais 12 têm peso 3. Isto é, 66\% correspondem à alta erosão. Isso se justifica pela presença de características físicas em que se destacam a granulometria média a grossa das areias praiais, a inexistência de sistema barra-calha e de zona de pós-praia. Em alguns trechos, a praia tem largura inferior a $20 \mathrm{~m}$ e a zona de pós-praia não chega a $1 \mathrm{~m}$. Tais condições refletem o alcance das marés altas, que quase diariamente cobrem todo o arco praial, e a ação das ondas que atingem a base das escarpas, ao longo da linha de costa. 
Figura 7 - Indicadores de erosão da orla Grande. A) parte norte: plataforma de abrasão e banco de cascalho; B) parte centro-sul: desmoronamento de falésias, destruição de muros, vigas, calçadas e escadarias; C) reconstrução do muro de contenção entre 2017 e 2018

A
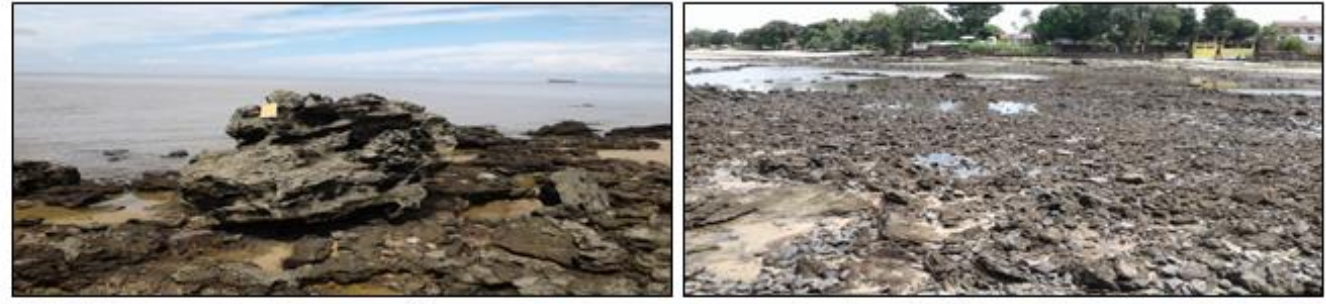

$\mathrm{B}$
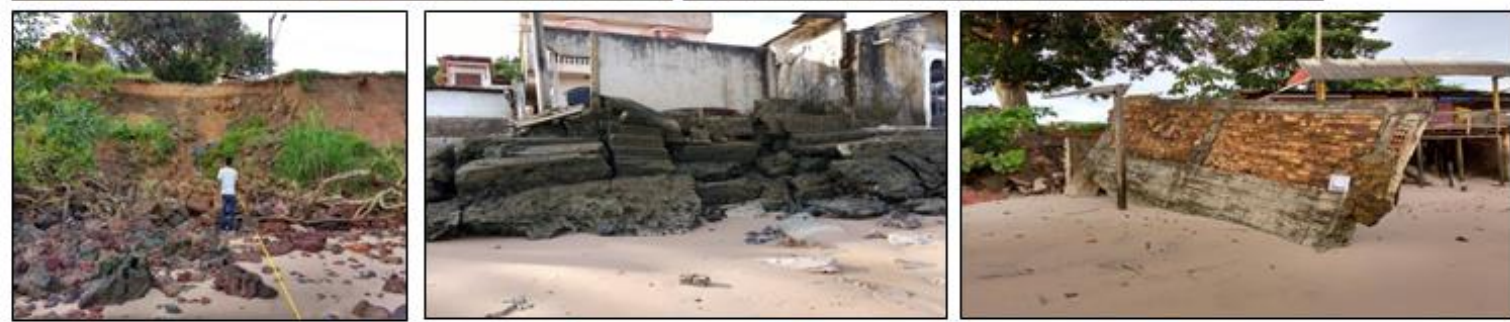

C
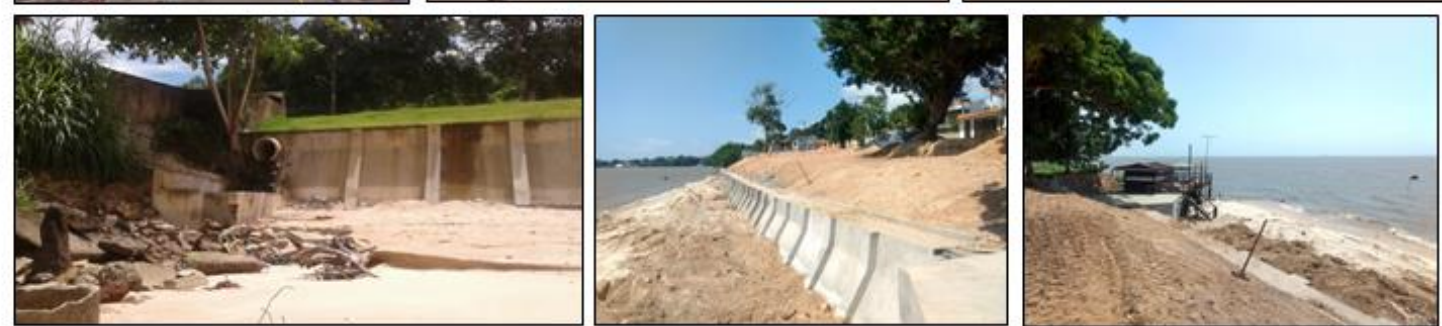

Fonte: Acervo particular dos autores (maio de 2016 e janeiro de 2019)

As falésias e promontórios estão entre os mais altos da área de estudo ( 3 a 5 m). As plataformas de abrasão, bancos de cascalho e feições erosivas lineares têm grande representatividade espacial, recobrindo mais de 50\% da extensão da orla. As construções situadas na porção superior da praia e no flanco das escarpas apresentam alicerces, pilares, vigas e tubulações expostos, devido à remoção de areia da zona superior do estirâncio (Figuras 8 e 9).

O mapa do grau de dinâmica costeira da orla Grande-Bispo demonstra que a erosão se manifesta com intensidade média e alta, atingindo tanto as praias como o rebordo dos platôs. Trata-se de um cenário em transformação, apontando para a necessidade do planejamento da ocupação e da implementação de políticas de gerenciamento. A adoção dos limites de segurança propostos por Muehe (2001), com a definição da faixa de orla, é fundamental tendo em vista a urgência de se promover melhorias na estabilidade da linha de costa e reduzir os danos causados à infraestrutura urbana. 
Figura 8 - Distribuição espacial dos indicadores dinâmicos atuais na orla do Bispo

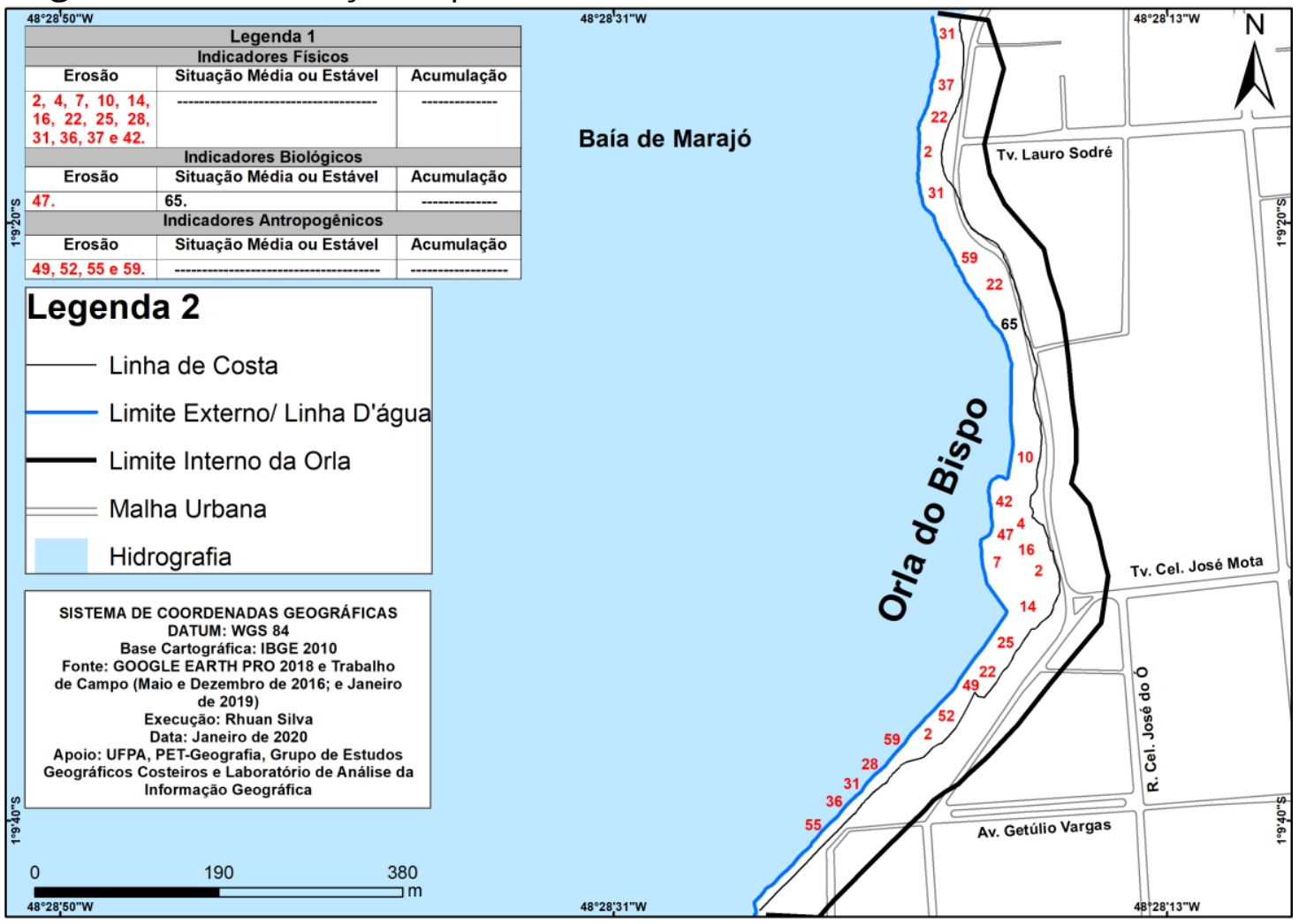

Organização dos autores (2020)

Figura 9 - Divisão da orla do Grande-Bispo em setores conforme o grau do fenômeno dinâmico

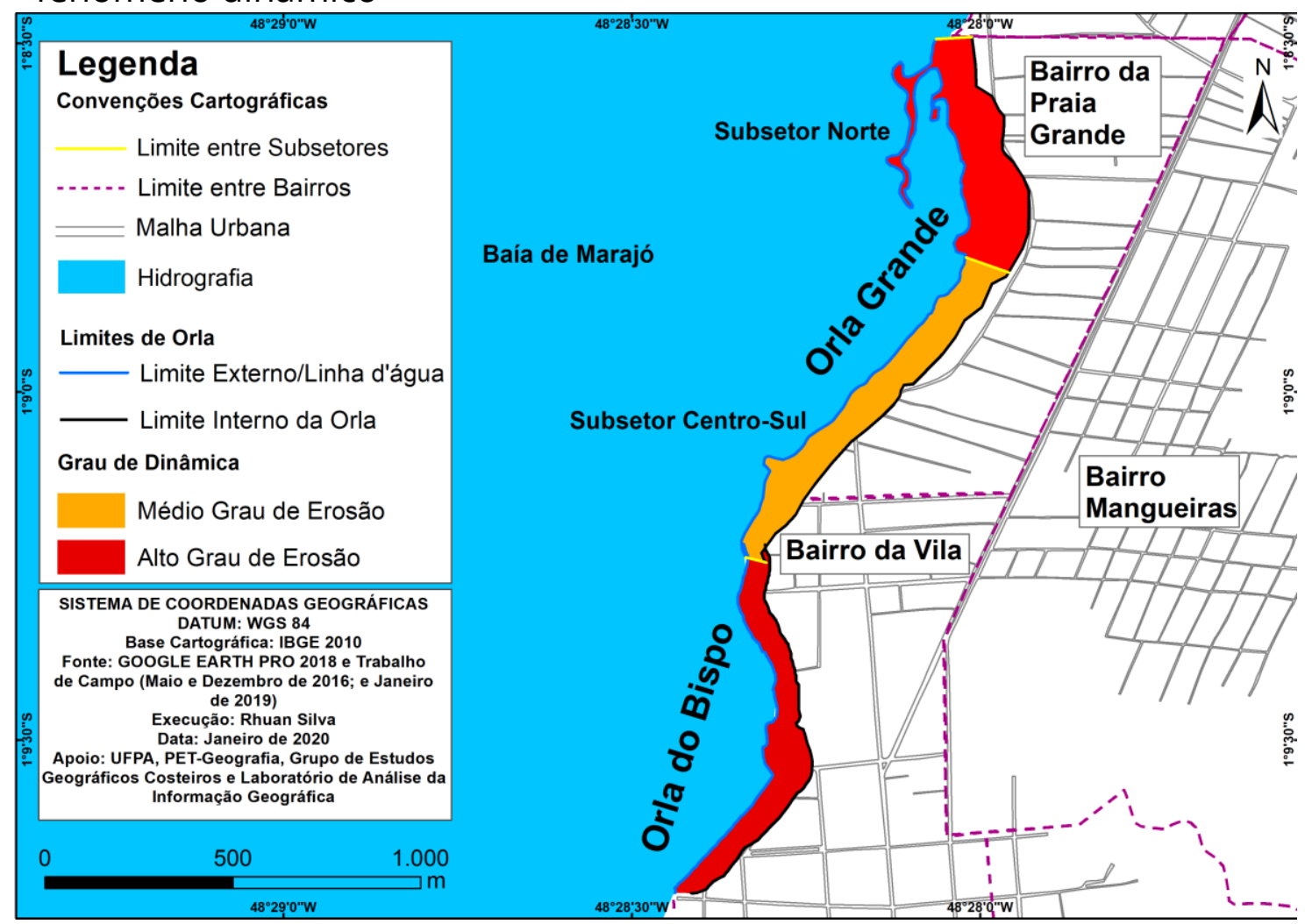

Organização dos autores (2020) 


\section{CONSIDERAÇÕES FINAIS}

O estudo acerca da dinâmica costeira da orla Grande-Bispo, ilha de Mosqueiro, Belém-PA, revelou o predomínio da erosão, que se manifesta com intensidade desigual ao longo da área. A análise foi pautada na variação, distribuição e quantificação de indicadores, em duas escalas têmporo-espaciais (médio e curto período), seguido de representação cartográfica.

A posição da linha de costa, considerada como um dos indicadores físicos, foi comparada dentro do intervalo temporal de 33 anos (1984-2017), através de imagens de satélite, demonstrando um comportamento diferenciado entre as orlas Grande e Bispo. As medidas de magnitude e taxa relativas a essa variação, mostraram que, na orla Grande, as áreas retrogradacionais totalizaram $13.500 \mathrm{~m}^{2} \pm 559 \mathrm{~m}^{2}$. O recuo médio linear chegou a $32 \mathrm{~m} \pm 18,6 \mathrm{~m}$, com taxa de 0,9 m/ano.

Esses dados sinalizam uma situação de baixa erosão, que é justificada pela ocorrência de falésias sedimentares margeadas por vias de transporte e pela ação de mesomarés. A orientação NE-SW da linha de costa facilita a influência de ondas que se deslocam de norte para sul, na baía de Marajó, com alturas que podem atingir de 1 a 1,5 m. A infraestrutura urbana com rede de microdrenagem inadequada ou sem manutenção, possibilita o escoamento livre das águas pluviais que atingem facilmente o rebordo das falésias.

$\mathrm{Na}$ orla do Bispo, quase não houve registro de deslocamento do rebordo das falésias e promontórios, atestando-se o predomínio da estabilidade da linha de costa. Trata-se de um comportamento dinâmico como resposta a um conjunto de fatores relacionados à ocupação urbana, tais como a instalação de estruturas de contenção em concreto, patamares aterrados e pavimentação alfáltica. Somam-se as condições do meio biofísico, representadas pela cobertura vegetal herbácea das falésias e pela presença de um campo de matacões. São fatores que exercem certo controle sobre a erosão.

A distribuição espacial de indicadores, obtidos através de inventário de campo, apontou, numa escala de curto período, características de outros fatores da dinâmica 
costeira, independentemente da variação da linha de costa, tais como a largura da praia, a localização da linha de maré alta, a granulometria da areia praial, a extensão relativa das plataformas de abrasão e bancos de cascalho, a altura e representatividade das falésias, o estado de conservação das construções e equipamentos urbanos e a presença de feições erosivas lineares e areolares. As características foram determinadas por parâmetros e pesos, definidos a partir de mensurações e registros feitos in loco.

A localização e a quantificação desses indicadores permitiram a divisão da orla Grande em dois subsetores: norte e centro-sul. No norte, $41 \%$ atestam erosão de alto grau, enquanto que no centro-sul, 61\% definem erosão de médio grau. E no Bispo, $66 \%$ dos indicadores revelam alta erosão.

O médio grau de erosão expressa-se por características morfométricas, assim sintetizadas: o arco praial tem largura que varia de 21 a 50 m; a superfície de póspraia pode alcançar de 1 a 2 m; as marcas de deslizamento, desabamento ou solapamento ocorrem em toda a extensão das falésias; os bancos de cascalho ocupam de 25 a 50\% da superfície da praia; as estruturas de sustentação das construções urbanas encontram-se expostas ou destruídas em 25 a 50\% da extensão da orla; as árvores e os arbustos das margens das falésias apresentam-se tombados com raízes expostas; e o desenvolvimento de feições erosivas lineares nas escarpas e na praia.

A erosão de alto grau é descrito pelos seguintes parâmetros: o arco praial apresenta largura inferior a 20 m; não existe zona de pós-praia ou, quando existente, possui largura inferior a $1 \mathrm{~m}$; as falésias e promontórios alcançam de 3 a $5 \mathrm{~m}$ de altura; as plataformas de abrasão, bancos de cascalho e feições erosivas lineares recobrem mais de $50 \%$ da extensão da orla.

Os dados relativos à variação da linha de costa, à compartimentação morfológica e ao tipo de ocupação serviram para a delimitação da largura da orla enquanto faixa de proteção. Quanto aos aspectos morfológicos, a orla é constituída de praias arenosas e falésias sedimentares ocupadas pelo uso urbano. Essas 
características associadas à baixa taxa de erosão da linha de costa permitiu a seguinte demarcação: o limite externo da orla foi fixado pela linha d'água (contato entre a parte emersa e submersa da praia) e o limite interno foi estabelecido pelo marco de 50 m, medido a partir da beira das falésias, estendendo-se na direção do interior, seguindo a superfície aplainada do baixo platô.

Assim, a orla Grande-Bispo configura-se como um polígono irregular com extensão de 2.950 m e larguras que variam de 50 m, nas partes mais estreitas, a 170 m, nas porções mais largas. É nessa faixa de proteção que o poder público deve estabelecer prioridades no sentido de implementar ações que garantam a conservação da orla. Os resultados deste estudo representam um diagnóstico que pode subsidiar futuras políticas de ordenamento e planejamento da ocupação.

\section{REFERÊNCIAS}

BATISTA, E. M.; SOUZA, P. W. M. FILHO; SILVEIRA, O. F. M. Monitoramento da linha de costa do Parque Nacional do Cabo Orange através de análise multitemporal de imagens de sensores remotos. In: XIII SIMPÓSIO BRASILEIRO DE SENSORIAMENTO REMOTO, Florianópolis. Anais... Florianópolis: INPE, 2007. p. 6621-6628.

BRASIL. Ministério da Defesa. Marinha do Brasil. Tábua das Marés. Ilha de Mosqueiro (Estado do Pará)-2018. Disponível em https://www.marinha.mil.br/chm/sites/www.marinha.mil.br.chm/files/dados_de_mare /ilha_do_mosqueiro_2018.pdf. Acesso em 12 de mar de 2018.

BRASIL. Ministério do Meio Ambiente. Panorama da erosão costeira no Brasil. Brasília, DF: MMA, 2018. Disponível em https://www.mma.gov.br/images/arquivo/80342/Panorama_erosao_costeira_Brasil.pd f. Acesso em 10 de jan de 2019.

BRASIL. Ministério do Meio Ambiente. Projeto Orla: fundamentos para gestão integrada. Brasília, DF: MMA/SQA; Brasília: MP/SPU, 2002. 78p.

BRASIL. Ministério do Meio Ambiente; Ministério do Planejamento, Orçamento e Gestão. Projeto Orla: Subsídios para um projeto de gestão. Brasília, DF: MMA; MP, 2004. 104 p. 
CAMPOS, W. V. S. et al. Influência da urbanização na erosão da área costeira na praia do Murubira, ilha de Mosqueiro-PA. In: XIV ENCONTRO NACIONAL DE ESTUDANTES DE ENGENHARIA AMBIENTAL, Brasília. Anais... Brasília: Editora Blucher, 2016. p. 548-555.

CHRISTOFOLETTI, A. Geomorfologia. São Paulo: Ed. Edgard Blücher Ltda., 1980.

COLTRINARI, L.; MCCALL, G. J. H. Geo-indicadores: ciências da terra e mudanças ambientais. Revista do Departamento de Geografia, São Paulo, vol. 9, p. 5-11, 1995.

CONTI, L. A.; RODRIGUES, M. Variação da linha de costa na região da ilha dos GuarásPA através de análise de série temporal de imagens de satélites. Revista Brasileira de Geografia Física, Recife, n. 5, p. 922-937, 2011.

EL-ROBRINI, M. et al. Pará. In: MUEHE, D. (Org.). Erosão e progradação do litoral brasileiro. Brasília: Ministério do Meio Amabiente e Programa de Geologia e Geofísica Marinha, 2006. p. 41-86.

FERREIRA, J. L. A. Jr. Caracterização morfológica e dinâmica da orla Grande, ilha de Mosqueiro, Belém-PA. Boletim Amazônico de Geografia, Belém, vol. 03, n. 06, p. 92109, jul./dez. 2016.

FORBES, D. L.; LIVERMAN, D. G. E. Geological indicators in the coastal zone. In: BERGER, A. R.; IAMS, W. J. (Ed.). Geoindicators. Assessing rapid environmental changes in earth systems. Rotterdam (Holanda): A. A. Balkema, 1996. p. 175-192.

FRANÇA, C. F. Morfologia e mudanças costeiras da margem leste da llha de Marajó (PA). 2003. 144 p. Tese (Doutorado em Geologia) - Universidade Federal do Pará, Belém.

FRANÇA, C. F.; SOUZA, P. W. M. FILHO Análise das mudanças morfológicas costeiras de médio período na margem leste da ilha de Marajó (PA) em imagem Landsat. Revista Brasileira de Geociências, São Paulo, vol. 33, n. 2 (Suplemento), p. 127-136, junho 2003.

FRANÇA, P. Jr.; VILLA, M. E. C. D. O ambiente geográfico e os geoindicadores. Revista Brasileira de Geografia Física, Recife, n. 2, p. 337-348, 2011.

IGREJA, H. L. S.; ALVES, R. J.; COSTA JÚNIOR, P. B. S. Estudos neotectônicos nas ilhas de Outeiro e Mosqueiro - NE do Estado do Pará. In: XXXVI CONGRESSO BRASILEIRO DE GEOLOGIA, Natal. Anais... Natal: SBG, 1990. Vol. 5, p.2110-2123.

MARTINS, K. A.; PEREIRA, P. S.; LINO, A. P.; GONÇALVES, R. M. Determinação da erosão costeira do Estado de Pernambuco através de geoindicadores. Revista Brasileira de Geomorfologia, Uberlândia, vol. 17, n. 3, p. 533-546, jul/set 2016.

MEIRA, A. FILHO. Mosqueiro ilhas e vilas. Belém: GRAFISA, 1978. 
MENESES, P. R.; ALMEIDA, T. Introdução ao Processamento de Imagens de

Sensoriamento Remoto. Brasília: Universidade de Brasília, Conselho Nacional de Desenvolvimento Científico, 2012. Disponível em:

http://www.cnpq.br/documents/10157/56b578c4-0fd5-4b9f-b82a-e9693e4f69d8. Acesso em 15 de jun de 2018.

MUEHE, D. Geomorfologia costeira. In: GUERRA, A. J. T.; CUNHA, S. B. (Orgs.).

Geomorfologia: uma atualização de bases e conceitos. Rio de Janeiro: Bertrand Brasil, 1994. p. 253-308.

MUEHE, D. Critérios morfodinâmicos para o estabelecimento de limites da orla costeira para fins de gerenciamento. Revista Brasileira de Geomorfologia, Uberlândia, vol. 2, n. 1, p. 35-44, 2001.

NEVES, S. C. R.; FRANÇA, C. F.; SILVA, R. R. P. Morfologia e dinâmica da orla costeira do Maraú, ilha de Mosqueiro, Belém, Pará. Geosul, Florianópolis, vol.34, n. 73, p. 107-125, set./dez. 2019.

PINHEIRO, R. V. L. Estudo hidrodinâmico e sedimentológico do estuário Guajará Belém(PA). 1987. 164p. Dissertação (Mestrado em Geologia) - Universidade Federal do Pará, Belém-PA.

Prefeito assina ordem de serviço para início das obras na orla de Mosqueiro. Agência Belém, 2017. Disponível em: http://agenciabelem.com.br/Noticia/153842/prefeitoassina-ordem-de-servico-para-inicio-das-obras-na-orla-de-mosqueiro. Acesso em 10 de fev de 2020).

RANIERI, L. A.; EL-ROBRINI, M. Evolução da linha de costa de Salinópolis, Nordeste do Pará, Brasil. Pesquisas em Geociências, Porto Alegre, vol. 42, n. 3, p. 207-226, set/dez 2015.

RODRIGUES, S. W. P.; SOUZA, P. W. M. FILHO Análise da variação da linha de costa a noroeste do Estado do Pará (baía de Curuçá) através de imagens Landsat TM e ETM ${ }^{+}$e CBERS 2B. In: XV SIMPÓSIO BRASILEIRO DE SENSORIAMENTO REMOTO, Curitiba. Anais... São José dos Campos: INPE, 2011. p. 5061-5069.

ROSS, J. L. S. O registro cartográfico dos fatos geomórficos e a questão da taxonomia do relevo. Revista do Departamento de Geografia, São Paulo, vol. 6, p. 17-29, 1992.

ROSSETTI, D. F. Late Cenozoic sedimentary evolution in northeastern Pará, Brazil, within the context of sea level changes. Journal of South American Earth Sciences, n. 14, p. 77-89, 2001.

SILVA, R. R. P.; FRANÇA, C. F. Indicadores dinâmicos da orla do Bispo, ilha de Mosqueiro, Belém-PA. Boletim Amazônico de Geografia, Belém, vol. 03, n. 06, p. 44-59, jul./dez. 2016. 
SILVA, M. V.; SANTOS, V. F.; SILVEIRA, O. F. M. Análise multitemporal de mudanças nas ilhas costeiras do Estado do Amapá aplicando dados de sensores remotos. In: XV SIMPÓSIO BRASILEIRO DE SENSORIAMENTO REMOTO, Curitiba. Anais... Florianópolis: INPE, 2011. p. 8614-8622.

SOUZA, C. R. G. A erosão nas praias do Estado de São Paulo: causas, consequências, indicadores de monitoramento e risco. In: BONONI, V. L. R.; SANTOS, N. A. Jr. (Org.). Memórias do Conselho Científico da Secretaria do Meio Ambiente: a síntese de um ano de conhecimento acumulado. São Paulo: Instituto de Botânica, Secretaria do Meio Ambiente do Estado de São Paulo, 2009. p. 48-69.

SOUZA, C. R. G. et al. Quaternário do Brasil. Ribeirão Preto: Holos Editora, 2005. 